\title{
Characterization of in vitro and in vivo Antiviral Activity of Lactoferrin and Ribavirin upon Hantavirus
}

\author{
Michael E. MURPHY'), Hiroaki KARIWA ${ }^{1)}$, Tetsuya MIZUTANI ${ }^{1)}$, Hiroki TANABE ${ }^{1)}$, Kumiko YOSHIMATSU'), \\ Jiro ARIKAWA ${ }^{2)}$ and Ikuo TAKASHIMA ${ }^{1) *}$ \\ ${ }^{1)}$ Laboratory of Public Health, Graduate School of Veterinary Medicine, Hokkaido University, Sapporo 060-0818 and ${ }^{2)}$ Institute for \\ Animal Experimentation, School of Medicine, Hokkaido University, Sapporo 060-0818, Japan
}

(Received 22 September 2000/Accepted 7 March 2001)

ABSTRACT. Mechanisms of anti-hantaviral activities of bovine lactoferrin (LF) and ribavirin (Rbv) were investigated. Hantavirus focus formation at $48 \mathrm{hr}$ was $15 \%$ of the control in cells treated with $400 \mu \mathrm{g} / \mathrm{ml} \mathrm{LF}$ for $1 \mathrm{hr}$ at $37^{\circ} \mathrm{C}$ prior to viral infection. Post infection treatment with $100 \mu \mathrm{g} / \mathrm{m} l \mathrm{Rbv}$ also inhibited the focus formation to $2.5 \%$ of the control. Combined LF pre- and Rbv post-infection treatment completely inhibited focus formation. Viral glycoprotein (G2) and nucleocapsid protein (NP) syntheses were delayed in LF pretreated cells up to $24 \mathrm{hr}$ post infection (hpi) but became comparable to the control by $48 \mathrm{hpi}$. Further, LF inhibited viral shedding at 24 hpi but did not inhibit shedding after 48 hpi. However, Rbv was able to inhibit synthesis of viral proteins, (+) and (-) strand RNAs also inhibited viral shedding after $24 \mathrm{hr}$. These results suggest that LF inhibits viral adsorption to cells, while Rbv inhibits viral RNA synthesis. For in vivo trials of LF and Rbv, LF pre- and Rbv post-treatment were evaluated in suckling mice infected with hantavirus, of which $7 \%$ survived. LF concentrations of 40 and $160 \mathrm{mg} / \mathrm{kg}$ administered prior to viral challenge improved survival rates to $15 \%$ and $70 \%$, respectively for single administration and $85 \%$ and $94 \%$, respectively, for double administration. Rbv concentrations of 25 and 50 $\mathrm{mg} / \mathrm{kg}$ gave survival rates of $68 \%$ and $81 \%$, respectively. This suggests that both LF and Rbv are efficacious in hantavirus infection in vivo.

KEY WORDS: confocal microscopy, hantavirus, lactoferrin, ribavirin, zoonosis.

J. Vet. Med. Sci. 63(6): 637-645, 2001

Hantavirus is a zoonotic, rodent-borne agent, which causes severe human diseases. Infected rodents are asymptomatic and can harbor the virus for a long period, shedding the virus in their excreta. To date, two distinct manifestations of hantavirus infection are known: one is hemorrhagic fever with renal syndrome (HFRS) endemic to Eurasia and the other is hantavirus pulmonary syndrome (HPS) endemic to the Americas [4, 5, 18, 19, 26, 29, 33].

Hantavirus is an enveloped negative-sense RNA virus belonging to the family Bunyaviridae [15, 34]. The genome consists of tripartite, single stranded RNAs which are designated S, M , and L RNA which encode nucleocapsid protein, glycoproteins (G1 and G2), and RNA polymerase, respectively [8, 32]. Such a characteristic as RNA synthesis is thought to be consistent in the family Bunyaviridae, to which the hantavirus belongs. One common characteristic of this family is RNA replication occurring in the cytoplasm. After the genome sense RNA is uncoated in the cytoplasm, the plus-strand RNA [mRNA and complimentary RNA (cRNA)] is synthesized. Viral proteins are translated from mRNA, and genome sense RNA is replicated by using cRNA as the template. Lactoferrin (LF), an antibacterial, iron-binding glycoprotein, was reported to manifest a broad antiviral activity [2, 23, 44]. In this study, we found that LF also inhibits in vitro hantavirus infection [28]. The mechanism appears to involve inhibition of virus adsorption to cells.

\footnotetext{
* Correspondence to: TaKashima, I., Laboratory of Public Health, Graduate School of Veterinary Medicine, Hokkaido University, Sapporo 060-0818, Japan.
}

Ribavirin (1- $\beta$-D-ribofuranosyl-1,2,4-triazole-3-carboxamide), a synthetic guanosine analog having broad spectrum antiviral properties to DNA and RNA viruses, acts through inhibition of viral RNA synthesis [10, 31, 39, 40]. We also found that Rbv exhibits in vitro anti-hantaviral activity [13, 28].

To further investigate possible mechanisms of anti-hantaviral activities of $\mathrm{LF}$ and $\mathrm{Rbv}$, these reagents were assessed in vitro in greater detail. Furthermore, these reagents were tested in vivo in mouse model. We found that mice treated with LF prior to infection or with Rbv at the time of infection, demonstrated increased survival rates. This is the first report describing in vivo inhibition of hantavirus by LF.

\section{MATERIALS AND METHODS}

Cells, viruses, and antiviral agents: Vero E6 cells were cultured in Eagle's minimum essential medium (Nissui Pharmaceutical Co., Ltd., Tokyo, Japan) supplemented with $5 \%$ fetal calf serum (ICN Biomedical Inc., Aurora, USA) and $0.03 \%$ L-glutamine (MEM) at $37^{\circ} \mathrm{C}$. SR-11 strain Seoul type hantavirus was propagated in Vero E6 cells and culture media of the infected cells stored at $-80^{\circ} \mathrm{C}$ as virus stock.

The virus foci were formed under MEM containing $1.5 \%$ carboxymethyl cellulose (CMC/MEM; Wako Pure Chemicals Ltd., Osaka, Japan) for 5 days at $37^{\circ} \mathrm{C}$. In our previously published report we described in detail the visualization of foci [28].

Bovine lactoferrin (LF; Wako Pure Chemical Industries, 
Ltd., Osaka, Japan) and ribavirin (Rbv; Yamasa Corp., Choushi, Japan) were evaluated in SR-11 infected cells.

Viral focus formation: Monolayers of Vero E6 cells were established on 24 well slides which were pretreated with $400 \mu \mathrm{g} / \mathrm{m} l \mathrm{LF}$ and/or $100 \mu \mathrm{g} / \mathrm{m} l \mathrm{Rbv}$ following infection with $5 \mathrm{ml}$ SR-11 for various periods of time. The time periods were as follows; untreated control, LF pretreatment one hr prior to virus infection ( -1 to $0 \mathrm{hr} \mathrm{LF}$ ), Rbv administered after viral infection for up to $48 \mathrm{hr}$ ( 0 to $48 \mathrm{hr} \mathrm{Rbv}$ ), and the combination of the above LF and Rbv treatments $(-1$ to $0 \mathrm{hr}$ $\mathrm{LF}$ with $0-48 \mathrm{hr} \mathrm{Rbv}$ ). In the case of LF pretreatment, at 0 hr, the LF was replaced with LF free 1.5\% CMC-MEM. Over the course of the $48 \mathrm{hr}$ experiment, cells were fixed with equal parts of acetone and methanol for $20 \mathrm{~min}$ at 0,1 , 2, 12, 24 and $48 \mathrm{hr}$. The 24 well slides were air-dried and stored at $-40^{\circ} \mathrm{C}$ until use. The slides were reacted with E5/ G6 monoclonal antibody [1] for $1 \mathrm{hr}$ at $37^{\circ} \mathrm{C}$, washed with PBS ( $\mathrm{pH}$ 7.6) and treated with anti-mouse IgG FITC conjugate. Foci were counted under a fluorescence microscope.

Evaluation of viral yield in cell culture fluid: Treatments of LF, Rbv, and LF/Rbv in combination were evaluated against Seoul virus infection in vitro. Vero E6 cell monolayers grown in $25 \mathrm{~cm}^{2}$ flasks were pretreated for $1 \mathrm{hr}$ with $400 \mu \mathrm{g} / \mathrm{m} l \mathrm{LF}$. SR-11 was inoculated on the cell monolayers (moi 0.001) and the cells were incubated in MEM for 1 hr at $37^{\circ} \mathrm{C}$ under $5 \% \mathrm{CO}_{2}$. The inoculum was discarded and the infected cells were cultured. The culture fluids were collected at $0,1,2,12,24$, and $48 \mathrm{hpi}$ and stored at $-80^{\circ} \mathrm{C}$ until use. The collected culture fluids were serially diluted and inoculated onto Vero E6 monolayers grown in 96 well plates. The cells were cultured in CMC-MEM for 5 days at $37^{\circ} \mathrm{C}$ under $5 \% \mathrm{CO}_{2}$ and fixed with acetone:methanol (1:1). The virus foci were visualized with anti-hantavirus nucleocapsid protein monoclonal antibody (NP); E5/G6 [1] and anti-mouse IgG FITC conjugate. The foci were counted under a fluorescence microscope. The virus yields were determined by calculating the means of four wells.

For Rbv, the time of treatment was subsequent to viral infection. Following infection of SR-11 to Vero E6 cells, $100 \mu \mathrm{g} / \mathrm{m} l \mathrm{Rbv}$ was added and cultured for $48 \mathrm{hr}$. The calculation of virus yields were determined by the above mentioned method.

For the combined treatment of LF/Rbv, the order of treatment and infection was as follows; LF pretreatment, SR-11 adsorption, and Rbv post-treatment.

Northern blot analysis: The 3' end of the Seoul virus S genome (1-805 nt) was cloned into pCR II (Invitrogen, Carlsbad, CA). The digoxigenin (DIG) labeled (-) and (+) RNA probes were prepared by DIG RNA Labeling Kit (Roche, Alameda, U.S.A.).

In vitro Rbv efficacy over time was evaluated in vitro on monolayers of Vero E6 cells grown in $25 \mathrm{~cm}^{2}$ flasks. Vero E6 cells infected with SR-11 were incubated with the antiviral reagent for various lengths of time. The time periods were as follows; untreated control, -1 to 1 days post infection (dpi), 0 to $1 \mathrm{dpi}, 0$ to $2 \mathrm{dpi}, 0$ to $3 \mathrm{dpi}, 0$ to $4 \mathrm{dpi}$, and 0 to $5 \mathrm{dpi}$. At the indicated dpi, Rbv MEM was replaced with
Rbv free MEM. At 5 dpi, the cells were washed 3 times with PBS, trypsinized with a $0.3 \%$ solution in PBS, collected with $10 \mathrm{~m} l \mathrm{MEM}$, and centrifuged to obtain a cell pellet. Total RNA was obtained by use of Isogen (Nippon Gene, Tokyo, Japan) according to the manufacturer's recommendations, and stored at $-80^{\circ} \mathrm{C}$. Total RNA $(5 \mu \mathrm{g})$ was denatured with a solution containing formamide, formaldehyde, $10 \times 3$-[N-morpholino] propanesulfonic acid (MOPS), ethidium bromide (EtBr) and double distilled water (DDW) for $5 \mathrm{~min}$ at $65^{\circ} \mathrm{C}$. Samples were then placed on ice for 5-10 min and were electrophoresed in $1 \%$ agarose gels. Gels were observed under UV and washed with $10 \times$ SSC for $30 \mathrm{~min}$. RNA was blotted onto a nylon membrane (Hybond-N+, Amersham, UK) overnight, exposed to UV for $3 \mathrm{~min}$, baked at $80^{\circ} \mathrm{C}$ for two hrs, and prehybridized with $10 \mathrm{ml}$ hybridization solution for $1 \mathrm{hr}$ at $68^{\circ} \mathrm{C}$. During hybridization, one membrane was treated with $2 \mathrm{ml}(-)$ RNA probe for detecting plus strand viral RNA, the other with $2 \mathrm{~m} l(+)$ RNA probe for detecting minus strand RNA in $10 \mathrm{~m} l$ hybrid solution, then incubated $12-16 \mathrm{hr}$ at $68^{\circ} \mathrm{C}$. Both membranes were washed vigorously and sealed in a hybridization bag and rocked for $30 \mathrm{~min}$. The membranes were first prewashed, then washed 3 times for $15 \mathrm{~min}$. The membranes were incubated with chemiluminescent substrate disodium 3-(4-methoxyspiro \{1,2-dioxetane-3,2'-(5'chloro)tricyclo[3.3.1.1 $1^{3,7}$ decan $\left.\}-4-y l\right)$ phenyl phosphate (CSPD; TROPIX, MA, U.S.A.) for $5 \mathrm{~min}$ at room temperature, sealed in hybridization bags, incubated for $15 \mathrm{~min}$ at $37^{\circ} \mathrm{C}$, and then exposed onto X-ray film.

Confocal imagery: Vero E6 cell monolayers were grown in 24-well (Eirie Sci. Co., NH) or 8-chamber slides (Becton Dickinson, NJ) in MEM. The cell monolayers were inoculated with $5 \mathrm{ml}$ SR-11 per well for $6 \mathrm{hr}$ at $4^{\circ} \mathrm{C}$ and the inoculum was removed. The groups of cells were; untreated controls, pretreated with $400 \mu \mathrm{g} / \mathrm{m} l \mathrm{LF}$ for $1 \mathrm{hr}$, post- treated with $100 \mu \mathrm{g} / \mathrm{ml} \mathrm{Rbv}$ for $1-48 \mathrm{hpi}$, and that receiving the combined treatment of LF and Rbv. The infected Vero E6 cells were incubated for $0,1,2,12,24$, or $48 \mathrm{hr}$ after adsorption at $37^{\circ} \mathrm{C}$. The monolayers were rinsed with phosphate buffered saline (PBS; pH 7.6) and fixed for $20 \mathrm{~min}$ in a mixture of equal parts of acetone and methanol. The slides were air-dried and stored at $-40^{\circ} \mathrm{C}$ until used. The cells were examined by confocal imagery.

In brief, concerning the confocal imagery procedure, the fixed cells were reacted with mouse monoclonal antibodies, $1 \mathrm{G} 8$ to hantavirus $\mathrm{G} 2$ proteins [46], E5/G6 to NP [1] or normal mouse serum for $1 \mathrm{hr}$ at $37^{\circ} \mathrm{C}$, washed in PBS, and followed by FITC conjugated anti-mouse serum IgG goat antibody (ICN Pharmaceuticals Inc., Aurora, USA) for $1 \mathrm{hr}$ at $37^{\circ} \mathrm{C}$. The antiviral effects of lactoferrin (LF; Wako Pure Chemical Industries, Ltd., Osaka, Japan) and ribavirin (Rbv; courtesy of Yamasa Corp., Choushi, Japan) were observed individually or concomitantly by microradiance confocal laser imagery (Bio-Rad Laboratories, Hercules, CA, U.S.A.) and localization of GP and NP translation was examined.

Evaluation of LF and Rbv in mice infected with SR-11: 


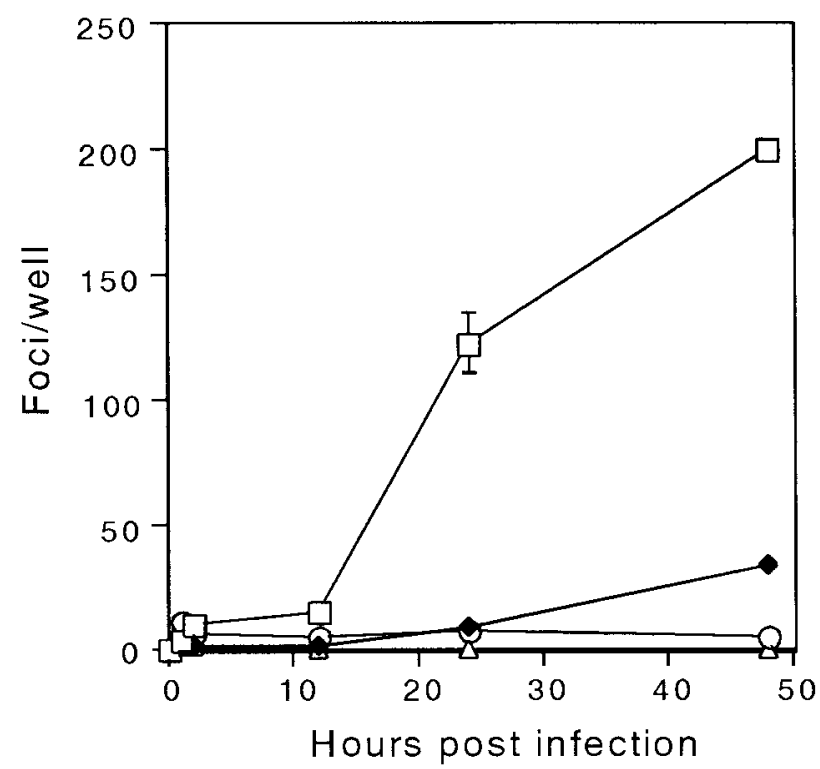

Fig. 1. Inhibition of hantavirus focus formation by LF and Rbv. Cells grown in 24-well slides were treated with $400 \mu \mathrm{g} / \mathrm{m} l \mathrm{LF}$ and/or $100 \mu \mathrm{g} / \mathrm{m} l \mathrm{Rbv}$ following infection with Seoul virus. The treatment regimens were as follows: MEM control $(\square) ;-1$ to $0 \mathrm{hr} \mathrm{LF}(\bigcirc)$; 0 to $48 \mathrm{hpi} \operatorname{Rbv}(\bigcirc) ;-1$ to $0 \mathrm{hr} \mathrm{LF}$ and 0 to 48 hpi $\operatorname{Rbv}(\Delta)$. Each symbol shows mean \pm s.e (although often not visible; $\mathrm{n}=8$ ). Cells were fixed at $0,1,2,12,24$ and $48 \mathrm{hr}$.

Suckling ICR mice were subcutaneously (sc) administered 10,40 , or $160 \mathrm{mg} / \mathrm{kg} \mathrm{LF}$ at 1 and/or 2 day(s) old (d.o.) and sc inoculated with SR-11 (100 FFU) at 3 d.o. Mice were observed for 25 days following infection. For Rbv evaluation, 3 d.o. mice were administered 25 or $50 \mathrm{mg} / \mathrm{kg} \mathrm{Rbv} 1 \mathrm{hr}$ after SR-11 infection and observed as above. All animal experiments were performed according to the experimental animal guidelines of the Graduate School of Veterinary Medicine, Hokkaido University.

\section{RESULTS}

Inhibition of hantavirus focus formation by $L F$ and Rbv: Hantaviral focus formation was evaluated in cells pretreated with $400 \mu \mathrm{g} / \mathrm{m} l \mathrm{LF}$ for $1 \mathrm{hr}$ at $37^{\circ} \mathrm{C}$. Focus numbers were $15 \%$ of those seen in the control group at $48 \mathrm{hr}$ (Fig. 1). From $24 \mathrm{hpi}$, cells pretreated with LF exhibited increasing foci. LF inhibited an early stage of infection such as adsorption as indicated in our previous study [28] but could not inhibit focus formation once the virus was adsorbed to the cells. However, Rbv could inhibit focus formation even though the virus was allowed to attach to the cell. Cells treated with $100 \mu \mathrm{g} / \mathrm{ml} \mathrm{Rbv}$ maintained hantavirus at low levels from an initial 11 foci at 2 hpi to 5 foci/well at $48 \mathrm{hpi}$. No foci were observed in cells treated with the combination of LF/Rbv after 12 hpi (Fig. 1).

Inhibition of hantavirus RNA synthesis by Rbv: In order to

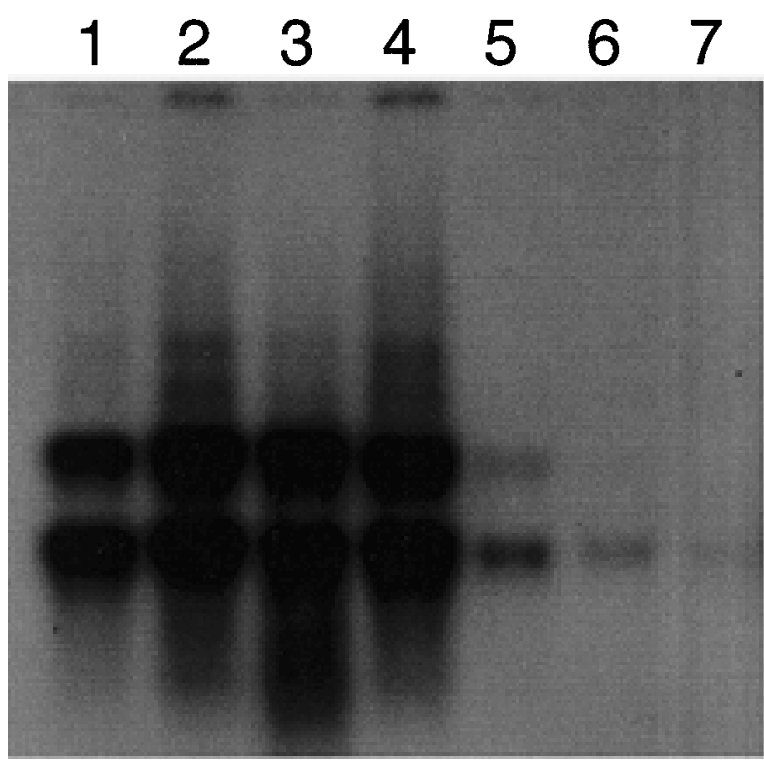

A

\section{$\begin{array}{lllllll}1 & 2 & 3 & 4 & 5 & 6 & 7\end{array}$}

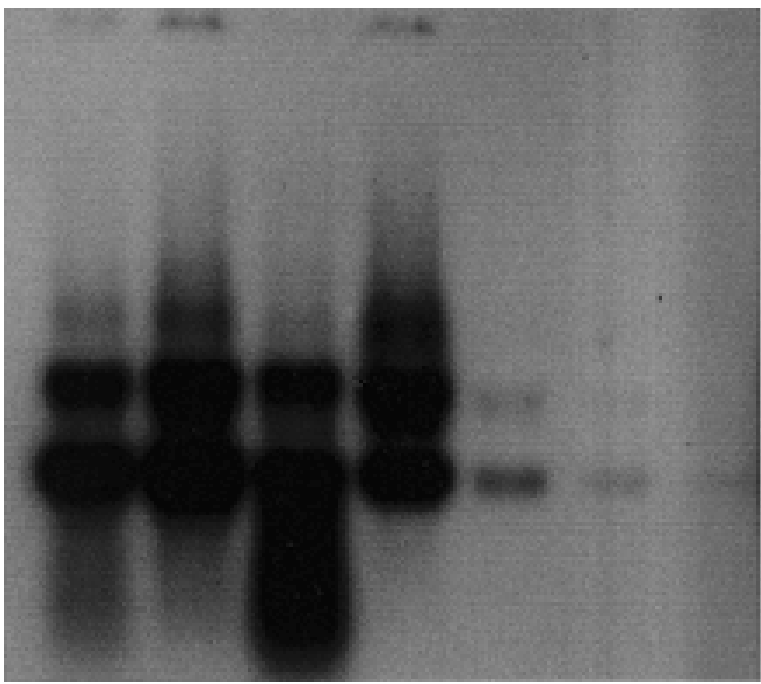

B

Fig. 2. Northern blot analysis for hantaviral RNA synthesis. Vero E6 cells grown in $25-\mathrm{cm}^{2}$ flasks were infected with a uniform concentration of SR-11 and cells were treated with $100 \mu \mathrm{g} / \mathrm{ml}$ Rbv at different times of onset column: 1) control, 2) -1 to $1 \mathrm{dpi}$, 3) 0 to $1 \mathrm{dpi}$, 4) 0 to $2 \mathrm{dpi}$, 5) 0 to $3 \mathrm{dpi}$, 6) 0 to $4 \mathrm{dpi}$, 7) 0 to 5 dpi. Cell pellets were obtained at $5 \mathrm{dpi}$ and total RNA extracted. Both the positive (A) and negative (B) strand genomes syntheses were equally prohibited. 


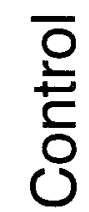
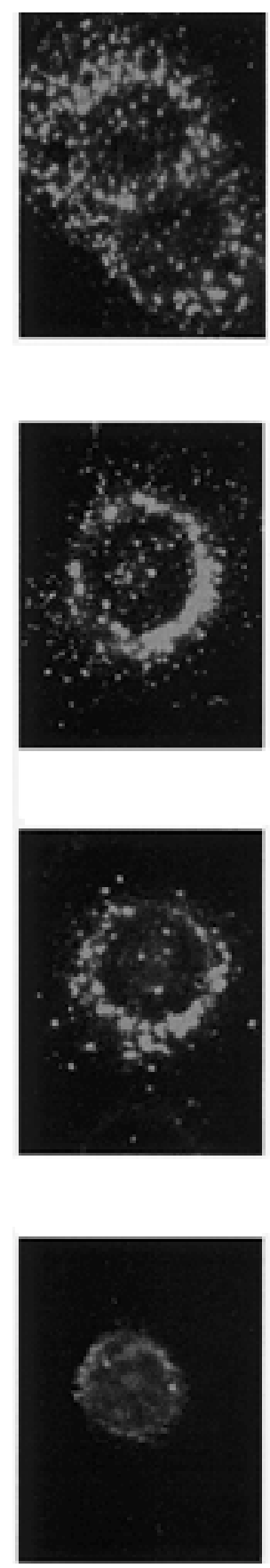
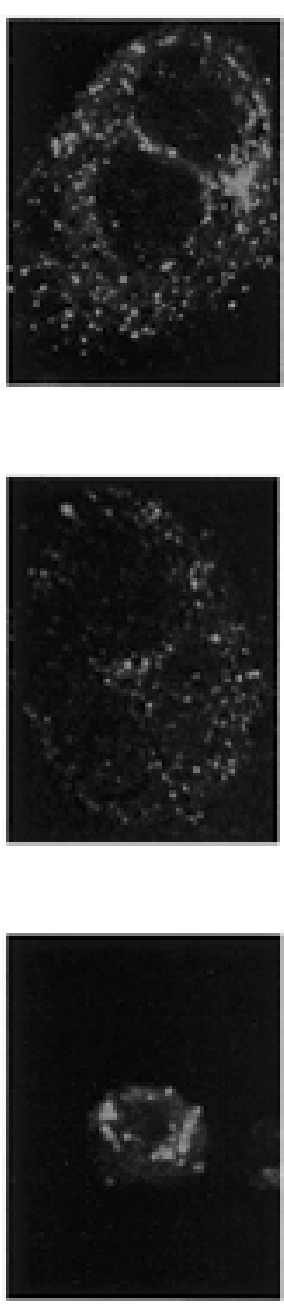

山

$\frac{a}{\alpha}$
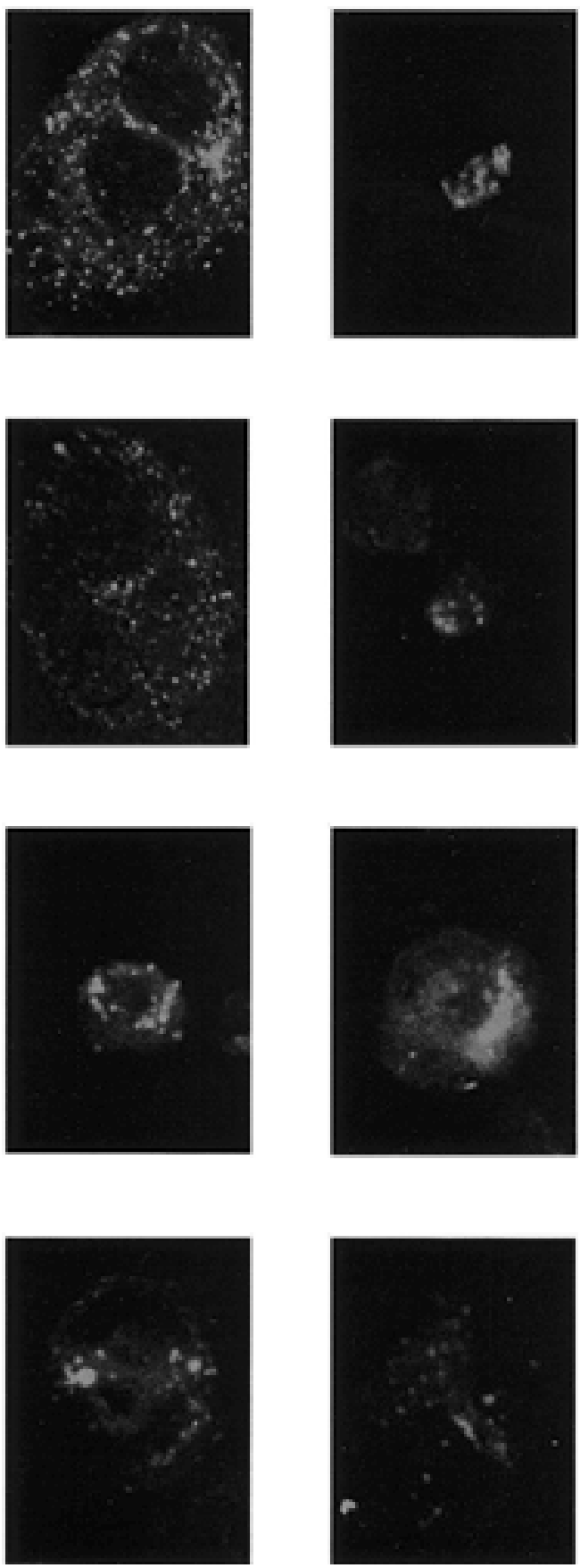
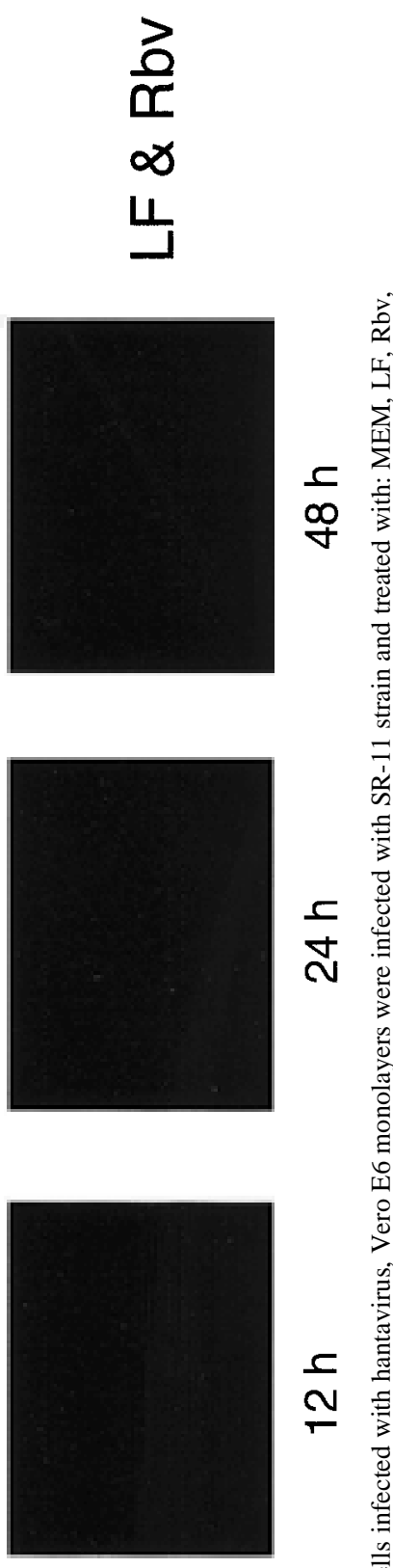

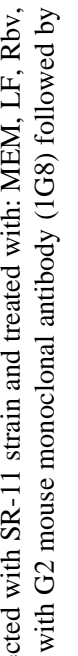

士

政

3

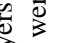

需

可

원ㅎㅇ

욜

$>$.

㣢 政

二 急产

N

品

总 范

구을

的刍

品罗

둥

政

웡

낭

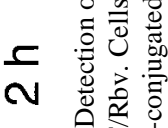

的界它 

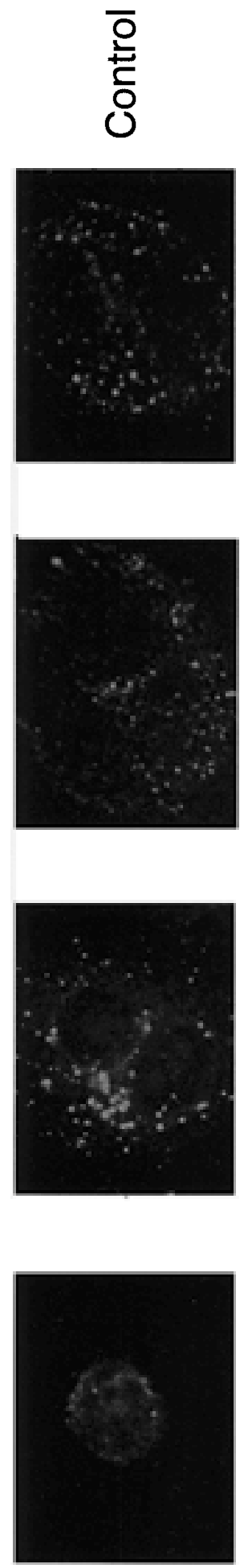

山
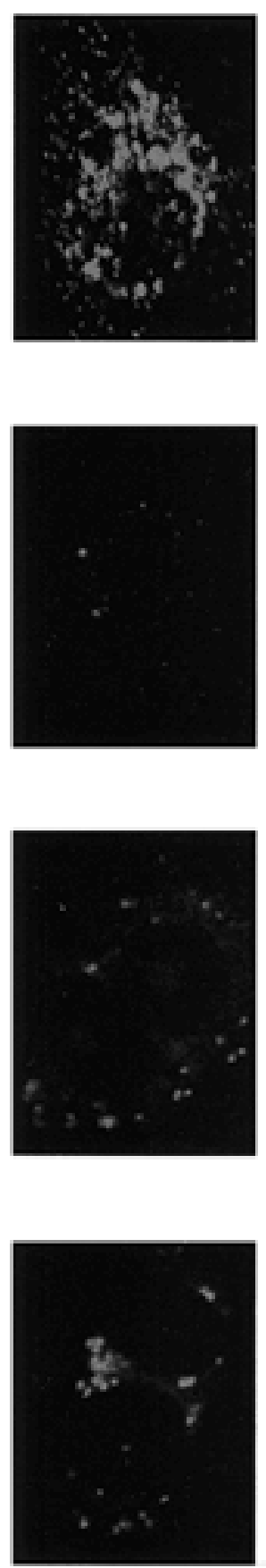

$\frac{3}{\square}$
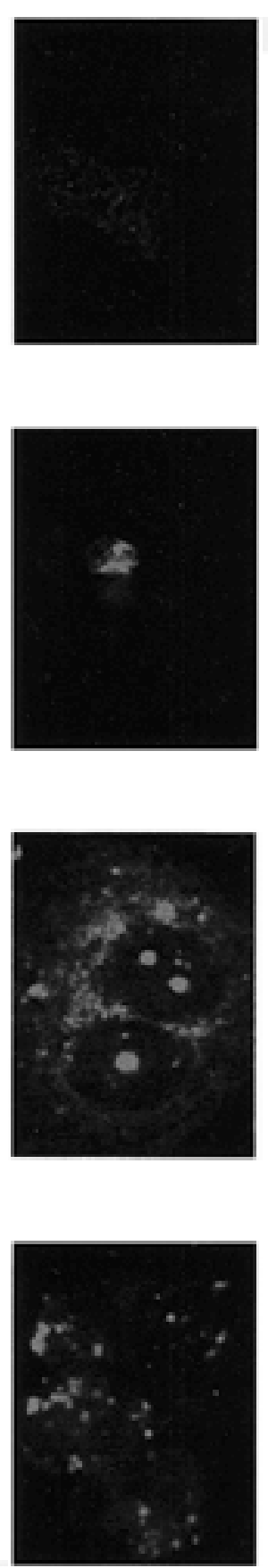

$\frac{7}{11}$
$\infty$
ㄴ
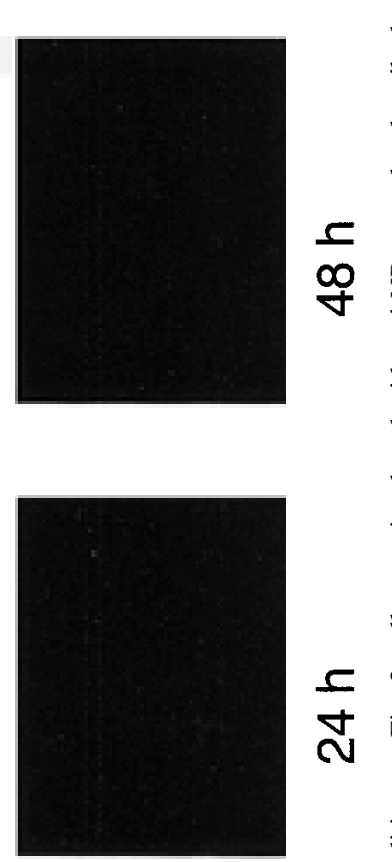

壳

约 m.

要

$\stackrel{0}{0}$

要

.

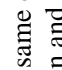

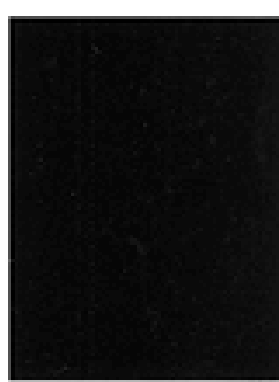

$\stackrel{0}{ \pm}$

홍응

5

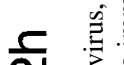

N

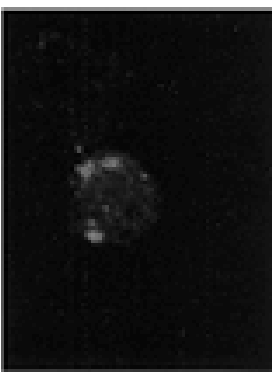

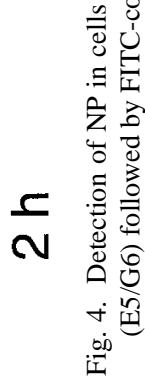




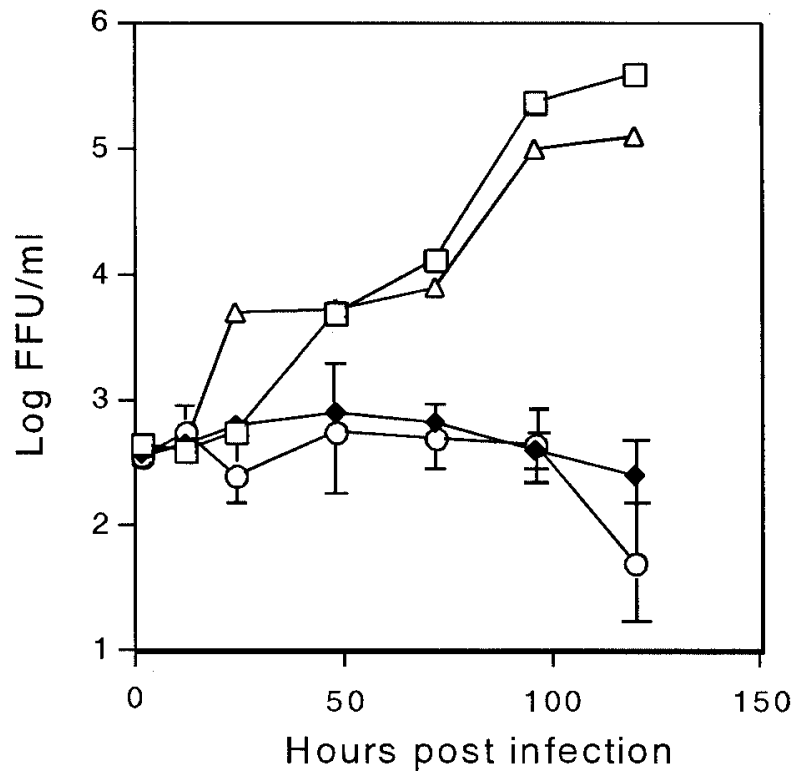

Fig. 5. Virus yield in culture fluid treated with LF and/or Rbv. Culture fluid was sampled at 1,12, 24, 48, 72, 96, and $120 \mathrm{hpi}$. Vero E6 monolayers were treated with $400 \mu \mathrm{g} / \mathrm{ml} \mathrm{LF}$ and/or 100 $\mu \mathrm{g} / \mathrm{m} l \mathrm{Rbv}$ and viral yield determined by titration. The reagents were as follows: control $(\Delta)$; -1 to $0 \mathrm{hr} \operatorname{LF}(\square) ; 0$ to $5 \mathrm{dpi} \mathrm{Rbv}$ (O); -1 to $0 \mathrm{hr}$ LF and 0 to 5 dpi Rbv (O). Each symbol shows mean \pm s.e $(n=8)$.

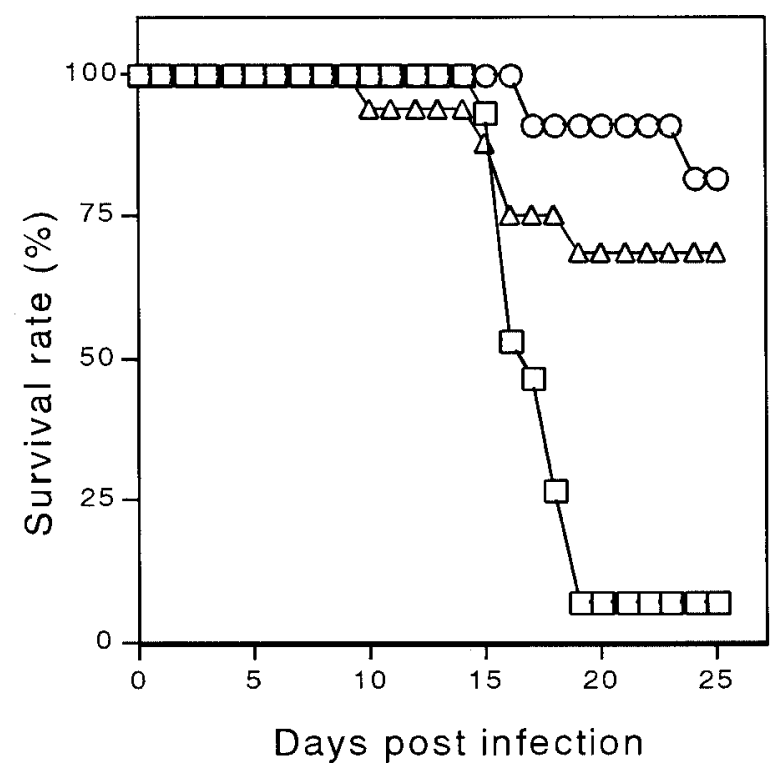

Fig. 6. Survival curve of hantavirus infected mice with Rbv administration. Suckling ICR mice infected with SR-11 strain (100 FFU/mouse) were subcutaneously (SC) administered in $\operatorname{MEM}(\square) ; 25 \mathrm{mg} / \mathrm{kg} \operatorname{Rbv}(\Delta) ;$ or $50 \mathrm{mg} / \mathrm{kg} \mathrm{Rbv}(\bigcirc)$ at 3 days old. Rbv treatment was initiated $1 \mathrm{hr}$ after infection.

determine whether Rbv acts on viral RNA synthesis, Northern blot analysis was performed on RNAs extracted from SR-11 infected Vero E6 cells at 5 dpi. DIG-labeled strand-

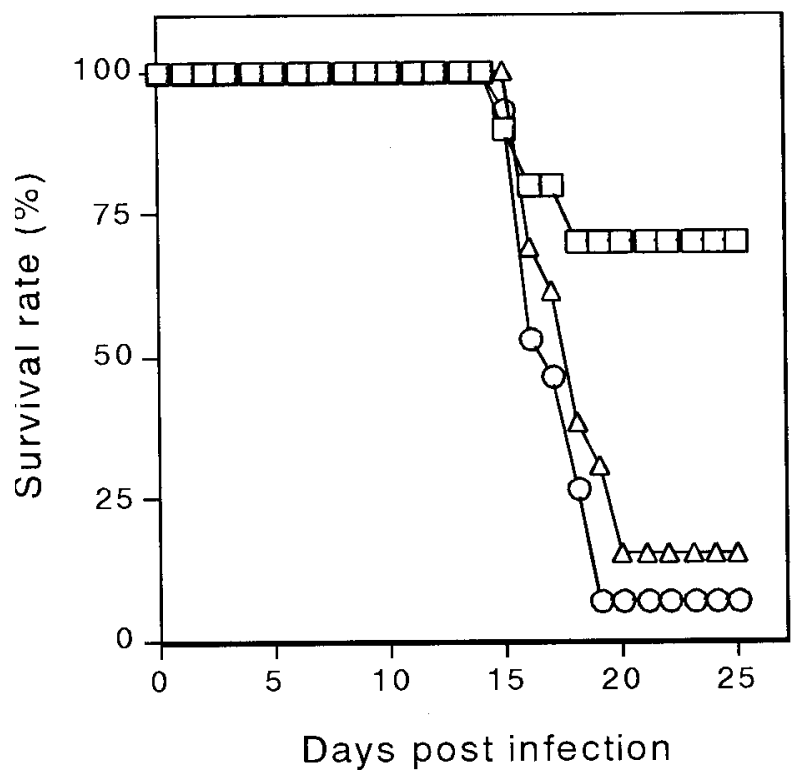

Fig. 7. Survival curve of hantavirus infected mice with LF single administration. Suckling ICR mice were administered (SC) with $0.1 \mathrm{ml}$ of the indicated concentrations of MEM (O); or $160(\square)$, or $40(\Delta) \mathrm{mg} / \mathrm{kg} \mathrm{LF}$ at 2 days old. All mice were inoculated with $0.1 \mathrm{~m} l$ SR-11 containing $100 \mathrm{FFU}$ on day 3 .

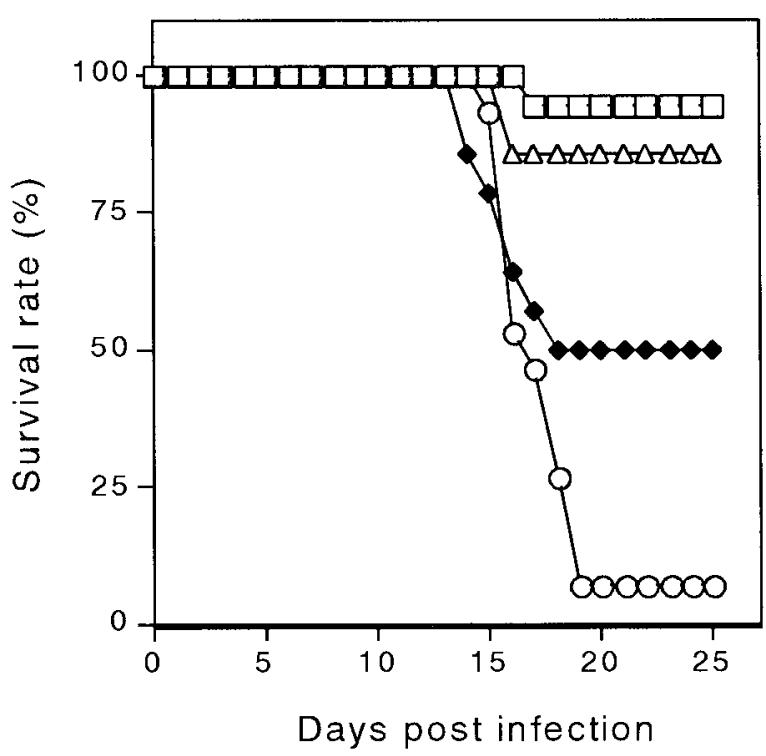

Fig. 8. Survival curve of hantavirus infected mice with LF double administration. Suckling ICR mice were treated with various concentrations of LF at 1 and 2 days old. Double administration of the MEM control ( $\bigcirc$ ); or $160(\square)$, or $40(\Delta)$, or $10 \mathrm{mg} / \mathrm{kg}$ LF ( $\bigcirc$ ) were administered SC 1 and 2 days prior to virus challenge at 3 days old.

specific RNA probes were utilized to detect genomic and antigenomic viral RNA (Fig. 2). Hantaviral genomic and antigenomic RNA syntheses were equally inhibited by Rbv 
treatment. Pretreatment and early treatment $(0-1$ and $0-2$ dpi) with Rbv exhibited no effect on viral RNA synthesis. However, 0-3, 0-4 and 0-5 dpi treatments inhibited viral RNA synthesis (Fig. 2, lanes 5 to 7).

Inhibition of hantavirus protein expression by $L F$ and $R b v$ : Viral glycoprotein (G2) expression was observed under a confocal laser microscope. At 2 hpi, G2 was detected in all cells treated with MEM, LF, Rbv, and LF/ Rbv (Fig. 3). The control and LF pretreated cells similarly showed increasing G2 expression by 48 hpi. Viral G2 expression in Rbv treated cells was inhibited after 12 hpi. The protein expression in cells treated with the combination of $\mathrm{LF} / \mathrm{Rbv}$ was completely inhibited from $12 \mathrm{hr}$ on.

Similar results were obtained concerning expression of NP as seen in Fig. 4.

Inhibition of virus shedding by $L F$ and $R b v$ : Viral yield of culture fluid at 24 hpi revealed a 10 fold difference between the control and LF pre-treated cell culture fluid (Fig. 5). This initial difference decreased over a period of time and from $48 \mathrm{hpi}$, these levels equalled those of the untreated cells. Culture fluid obtained from cells treated with $\mathrm{Rbv}$ demonstrated inhibition of viral shedding from $24 \mathrm{hr}$. Combined $\mathrm{LF} / \mathrm{Rbv}$ treatment revealed synergistically reduced virus yield by 120 hpi.

Efficacy of Rbv in mouse model: In mice infected with Seoul virus, the anti-hantaviral efficacy of ribavirin was evaluated by administration at $1 \mathrm{hpi}$. The survival rates of mice sc infected with 100 focus forming units (FFU) (30 $\mathrm{LD}_{50}$ ) of SR-11 were $6.7 \%$ for a period of 25 days (Fig. 6). The survival rates in Rbv treated mice were dose dependent. The administration of 50 and $25 \mathrm{mg} / \mathrm{kg} \mathrm{Rbv}$ gave survival rates of 81.8 and $68.8 \%$, respectively.

Efficacy of LF single and double administration: Under the conditions similar to those of Rbv administration, suckling mice were sc administered a single dose of 160 or 40 $\mathrm{mg} / \mathrm{kg} \mathrm{LF}$ or MEM 1 day prior to viral challenge (Fig. 7). Survival rates of these groups were $70,15.4$ and $6.7 \%$, respectively. Suckling mice were sc double administered 160,40 , or $10 \mathrm{mg} / \mathrm{kg} \mathrm{LF}$ or MEM 2 days and 1 day prior to viral challenge (Fig. 8). The survival rates of these groups were $94.1,85.7,50$ and $6.7 \%$, respectively, in a dose dependent manner.

\section{DISCUSSION}

In this study, antiviral agents were tested against SR-11 strain of hantavirus Seoul type. The reagents used were bovine lactoferrin, an iron binding glycoprotein found to have anti-bacterial, -fungal and -viral properties [2, 23, 44] and ribavirin, a synthetic guanosine analog noted for its broad spectrum antiviral properties to both DNA and RNA viruses through inhibition of viral RNA synthesis [10, 31, $39,40]$. Rbv is known to inhibit viruses such as arenavirus, coxsackievirus, Influenza viruses, La Crosse virus, and respiratory syncytial virus and other viruses [3,12-14, 24, 27, $30,39,40,42]$.

We previously reported that LF and Rbv inhibited han-
Table 1. Summarization of in vitro antihantaviral characteristrics of $\mathrm{LF}$ and $\mathrm{Rbv}$

\begin{tabular}{lcc}
\hline Activity inhibited & LF & Rbv \\
\hline Adsorption & + & - \\
Focus formation & \pm & + \\
RNA synthesis & - & + \\
Protein synthesis & \pm & + \\
\hline
\end{tabular}

tavirus infection in vitro [28]. The concentration of LF was previously found to have no cytotoxicity even at $5 \mathrm{mg} / \mathrm{m} l$ [28] and Rbv demonstrated minimal cytotoxicity when the dosage was under $2.5 \mathrm{mg} / \mathrm{ml}$ as determined by trypan blue exclusion test (data not shown). Therefore, the amounts used in the present experiment were well below the cytotoxic levels. We further confirmed that inhibition of hantavirus infection by LF was due to reduction of virus adsorption as found in polio virus, herpes simplex type 1, human cytomegalovirus, and HIV [9, 11, 21, 22, 43] as opposed to Hepatitis $\mathrm{C}$ in which LF has been found to directly bind viruses and inhibit viral infection $[16,17,45]$.

To further elucidate the efficacy and possible mechanisms of LF and Rbv upon hantavirus, these reagents were evaluated in vitro and in vivo in greater detail. In vitro, we examined the effects of both reagents upon focus formation, RNA synthesis, antigen production and infectious titer of hantavirus.

LF or Rbv treatment could reduce the number of foci but could not completely inhibit their formation. While no foci were observed in the combined treatment of $\mathrm{LF} / \mathrm{Rbv}$ from 12-48 hr, thus indicating a synergistic effect of these reagents. This corroborates our previous findings that pretreatment with LF and subsequent treatment with Rbv synergistically reduces viral focus formation in early infections [28].

The genome minus strand RNA and plus strand RNA syntheses were greatly and equally reduced by Rbv, but viral RNA synthesis was not completely inhibited (Fig. 2). However, in this condition, viral shedding was completely prohibited [28]. While in the control, viral shedding was continuous through 5 dpi (Fig. 5). Other investigators have reported subsequent elevations of viral RNA to original levels following removal or deterioration of $\mathrm{Rbv}[27,35]$. This indicates Rbv inhibits viral transcription and reduces infectivity, however, Rbv solely, cannot completely eliminate the virus.

Hantavirus G2 and NP protein translation was not reduced by LF once the infection was established in each cell (Figs. 3 and 4). However, Rbv demonstrated a pattern in which the foci of infected cells became more discreet over time, few foci were observed by $48 \mathrm{hr}$. This supports the hypothesis that Rbv actively inhibits viral protein expression within the cell and does not inhibit viral adsorption $[14,40]$. The absence of viral protein expression by $\mathrm{Rbv}$ does not exclude the presence of viral RNA. Under the conditions of reduced viral RNA synthesis, the virus may not express sufficient amounts of protein to be detected by IFA. 
The combination of $\mathrm{LF} / \mathrm{Rbv}$ revealed no discernible protein expression from $12 \mathrm{hr}$, for G2 and NP, clearly emphasizing the synergistic effects of the two reagents at the level of protein synthesis.

Viral yield was determined in SR-11 infected Vero E6 cells. The virus yield of culture fluid again demonstrated an early hantaviral inhibition by LF at $24 \mathrm{hr}$ which becomes less effective over time, equalling the control by $48 \mathrm{hr}$ (Fig. 5). This further supports the concept that LF inhibits adsorption although, once a viral infection is established, the $\mathrm{LF}$ is no longer efficacious in vitro. However, Rbv which has been demonstrated to act within the cell against several viruses $[14,40]$, shows a greatly reduced yield continuously from $24-120 \mathrm{hr}$. The combination of $\mathrm{LF} / \mathrm{Rbv}$ also reveals a reduced viral yield which slightly indicates synergy by 120 hr (Fig. 5).

Mice administered Rbv 1 hpi revealed an improved survival rate. The administration of 50 and $25 \mathrm{mg} / \mathrm{kg} \mathrm{Rbv}$ gave 81.8 and $68.8 \%$ survival rates, respectively (Fig. 6). The same result was reported by Huggins et al. [13]. This may be due to the inhibition of the viral RNA synthesis, which we observed in the in vitro evaluation portion of this study.

Mice administered LF one day prior to hantavirus inoculation had an improved survival rate of $70 \%$ for $160 \mathrm{mg} / \mathrm{kg}$ (Fig. 7). As seen in in vitro, this may be due in part to the inhibition of viral adsorption to target cells in vivo as well. Double administration of LF enhanced the survival rate. The 160 and $40 \mathrm{mg} / \mathrm{kg}$ double administrations resulted in $94.1 \%$ and $85.7 \%$ survival rates, respectively (Fig. 8). The difference between single and double administrations of LF may correlate to insufficient time for complete LF absorption in the single dose mice or an accumulative effect of LF in the body from the two administrations. Another possible difference may be that a certain period of time is necessary for LF to activate the immune system. LF has been demonstrated to enhance cytotoxic activities of monocytes $[2,25]$ and NK cells $[6,7,36,37]$. To evaluate augmentation of the immune system by LF, another in vivo experiment should be carried out by using older but susceptible mice, or by quantitative virus detection assay.

This study presents findings of anti-hantaviral activity by Rbv and LF. Further studies concerning LF activity may provide insight into effective clinical uses as a protective and a possible curative agent of hantavirus. LF and Rbv combination therapy may even be used as a measure for hantavirus infection in humans.

ACKNOWLEDGEMENTS. This study was supported in part by the Grants-in-aid for Scientific Research (A) and (C) from the Ministry of Education (No. 10306019 and 10660296, respectively), Science, Sports and Culture of Japan. Further, we would like to thank the Yamasa Corporation of Choushi, Japan for kindly contributing ribavirin.

\section{REFERENCES}

1. Arikawa, J., Schmaljohn, A., Dalrymple, J. and Schmaljohn, C.
1989. Characterization of Hantaan virus envelope glycoprotein antigenic determinants defined by monoclonal antibodies. $J$. Gen. Virol. 70: 615-624.

2. Bullen, J. and Armstrong, J. 1978. The role of lactoferrin in the bactericidal function of polymorphonuclear leucocytes. Immunology 36: 781-791.

3. Cassidy, L. and Patterson, J. 1989. Mechanism of La Crosse virus inhibition by ribavirin. Antimicrobiol. Agents Chemother. 33: 2009-2011.

4. CDC 1993. Update: hantavirus pulmonary syndrome--United States, 1993. MMWR Morb. Mortal. Wkly. Rep. 42: 421-424.

5. Clement, J., Heyman, P., McKenna, P., Colson, P. and AsvicZupanc, T. 1997. The hantaviruses of Europe: from the bedside to the bench. (review). Emerg. Infect. Dis. 3: 205-211.

6. Damiens, E., El Yazidi, I., Mazurier, J., Elass-Rochard, E., Duthille, I., Spik, G. and Boilly-Marer, Y. 1998. Role of heparan sulphate proteoglycans in the regulation of human lactoferrin binding and activity in the MDA-MB-231 breast cancer cell line. Eur. J. Cell. Biol. 77: 344-351.

7. Damiens, E., Mazurier, J., El Yazidi, I., Masson, M., Duthille, I., Spik, G. and Boilly-Marer, Y. 1998. Effects of lactoferrin on NK cell cytotoxicity against haematopoietic and epithelial tumor cells. Biochem. Biophys. Acta. 1402: 277-287.

8. Elliott, R. 1990. Molecular biology of the Bunyaviridae. J. Gen. Virol. 71: 501-522.

9. Fujihara, T. and Hayashi, K. 1995. Lactoferrin inhibits herpes simplex virus type-1 (HSV-1) infection to mouse cornea. Brief Report. Arch. Virol. 140: 1469-1472.

10. Goswami, B., Borek, E. and Sharma, O. 1979. The broad spectrum antiviral agent ribavirin inhibits capping of mRNA. Biochem. Biophys. Res. Commum. 89: 830-836.

11. Harmsen, M., Swart, P., de Bethune, M., Pauwels, R., De Clercq, E., The, T. H. and Meijer, D. 1995. Antiviral effects of plasma and milk proteins: lactoferrin shows potent activity against both human immunodeficiency virus and human cytomegalovirus replication in vitro. J. Infect. Dis. 172: 380388.

12. Hruska, J., Morrow, P., Suffin, S. and Douglas, R. Jr. 1982. In vivo inhibition of respiratory syncytial virus by ribavirin. Antimicrob. Agents Chemother. 21: 125-130.

13. Huggins, J., Hsiang, C., Cosgriff, T., Guang, M., Smith, J., Wu, Z.O., LeDuc, J., Meegan, J., Wang, Q., Oland, D., Gui, X., Gibbs, P., Yuan, G. and Zhang, T. 1991. Prospective, doubleblind, concurrent, placebo-controlled clinical trial of intravenous ribavirin therapy of hemorrhagic fever with renal syndrome. J. Infect. Dis. 164: 1119-1127.

14. Huggins, J., Robins, R. and Canonico, P. 1984. Synergistic antiviral effects of ribavirin and the $\mathrm{C}$-nucleoside analogs tiazofurin and selenazofurin against togaviruses, bunyaviruses, and arenaviruses. Antimicrob. Agents Chemother. 26: 476-480.

15. Hung, T., Xia, S., Zhou, J., Song, G., Liao, G., Ye ,W., Chu, Y. and Hang, C. 1983. Morphological evidence for identifying the viruses of hemorrhagic fever with renal syndrome as candidate members of the Bunyaviridae family: Brief Report. Arch. Virol. 78: 137-144.

16. Ikeda, M., Nozaki, A., Sugiyama, K., Tanaka, T., Naganuma, A., Tanaka, K., Sekihara, H., Shimotono, K., Saito, M. and Kato, N. 2000. Characterization of antiviral activity of lactoferrin against hepatitis $\mathrm{C}$ virus infection in human cultured cells. Virus Res. 66: 51-63.

17. Ikeda, M., Sugiyama, K., Tanaka, T., Tanaka, K., Sekihara, H., Shimotono, K. and Kato, N. 1998. Lactoferrin markedly inhibits hepatitis $\mathrm{C}$ virus infection in cultured human hepatocytes. 
Biochem. Biophys. Res. Commun. 245: 549-553.

18. Lee, H., Lee, P., Baek, L. and Chu, Y. 1990. Geographical distribution of hemorrhagic fever with renal syndrome and hantaviruses. Arch. Virol. (S1) 5-18.

19. Lee, H. and van der Groen, G. 1989. Hemorrhagic fever with renal syndrome. (review) Prog. Med. Virol. 36: 62-102.

20. Lu, L., Hangoc, G., Oliff, A., Chen, L., Shen, R-N. and Broxmeyer, H. 1987. Protective influence of lactoferrin on mice infected with the polycythemia-inducing strain of Friend Virus Complex. Cancer Res. 47: 4184-4188.

21. Marchetti, M., Superti, F., Ammendolia, M., Rossi, P., Valenti, P. and Seganti, L. 1999. Inhibition of poliovirus type 1 infection by iron-, manganese- and zinc-saturated lactoferrin. Med. Microbiol. Immunol. 187: 199-204.

22. Marchetti, M., Longhi, C., Conte, M., Pisani, S., Valenti, P. and Seganti, L. 1996. Lactoferrin inhibits herpes simplex virus type 1 adsorption to Vero cells. Antiviral Res. 29: 221-231.

23. Masson, P., Heremans, J. and Schonne, E. 1969. Lactoferrin, an iron binding protein in neutrophilic leucocytes. J. Exp. Med. 130: 643-658.

24. McClung, H., Knight ,V., Gilbert, B., Wilson, S., Quarles, J. and Divine, G. 1983. Ribavirin aerosol treatment of influenza B virus infection. J. Am. Med. Assoc. 249: 2671-2674.

25. McCormick, J., Markey, G. and Morris, T. 1991. Lactoferrininducible monocyte cytotoxicity for K562 cells and decay of natural killer lymphocyte cytotoxicity. Clin. Exp. Immunol. 83: 154-156.

26. Mertz, G. and Chapman, L. 1996. Hantavirus infections in the United States: diagnosis and treatment. (review). Adv. Exp. Med. Biol. 394: 153-162.

27. Mizutani, T., Inagaki, H., Araki, K., Kariwa, H., Arikawa, J. and Takashima, I. 1998. Inhibition of Borna disease virus replication by ribavirin in persistently infected cells A Brief report, Arch. Virol. 143: 2039-2044.

28. Murphy, M., Kariwa, H., Mizutani, T., Yoshimatsu, K., Arikawa, J. and Takashima, I. 2000. In vitro antiviral activity of lactoferrin and ribavirin upon hantavirus. Arch. Virol. 145: 1571-1582.

29. Nichol, S., Spiropoulou, C., Morzunof, S., Rollin, P., Ksiazek, T., Feldmann, H., Sanchez, A., Childs, J., Zaki,S. and Peters, C. 1993. Genetic identification of a hantavirus associated with an outbreak of acute respiratory illness. Science 262: 914-917.

30. Okada, I., Matsumori, A., Matoba, Y., Tominaga, M., Yamada, T. and Kawai, C. 1992. Combination treatment with ribavirin and interferon for Coxsackievirus B3 replication. J. Lab. Clin. Med. 120: 569-573.

31. Patterson, J. and Fernandez, L. 1990. Molecular mechanisms of action of ribavirin. Rev. Infect. Dis. 12: 1139-1146.

32. Plyusnin, A., Vapalahti, O. and Vaheri, A. 1996. Hantaviruses: genome structure, expression and evolution. J. Gen. Virol. 77:
2677-2687.

33. Rai, S., Shibata, H., Matsumura, T., Uga, S., Nakagawa, M., Maehara, T., Ono, K., Sumi, K. and Matsuoka, A. 1997. Seroepidemiological Study of Hantavirus Infection in Nepal. JARMAM 8: 81-86.

34. Schmaljohn, C. and Dalrymple, J. 1983. Analysis of Hantaan Virus RNA: evidence for a new genus of Bunyaviridae. Virology 131: 482-491.

35. Severson, W., Javadian, M. and Jonsson, C. 1998. Effect of ribavirin on Hantaan virus replication. p. 100. In: The Fourth International Conference on HFRS and Hantaviruses; Atlanta, Georgia CDC U.S. Dept. of Hlth. \& Hum. Serv.

36. Shau, H., Kim, A. and Golub, S. 1992. Modulation of natural killer and lymphokine-activated killer cell cytotoxicity by lactoferrin. J. Leukoc. Biol. 51: 343-349.

37. Shimazaki, K., Tazume, T., Uji, K., Tanaka, M., Kumura, H., Mikawa, K. and Shimooka, T. 1998. Properties of a heparinbinding peptide derived from bovine lactoferrin. J. Dairy Sci. 81: 2841-2849.

38. Shimizu, K., Matsuzawa, H., Okada, K.,Tazume, S., Dosako, S., Kawasaki, Y., Hashimoto, K. and Koga, Y. 1996. Lactoferrin-mediated protection of the host from murine cytomeglovirus infection by a T-cell-dependent augmentation of natural killer cell activity. Arch. Virol. 141: 1875-1889.

39. Sidwell, R., Robins, R. and Hillyard, I. 1979. Ribavirin: an antiviral agent. Pharmacol. Ther. 6: 123-146.

40. Streeter, D., Witkowski, J., Khare, P., Sidwell, R., Bauer, R., Robins, R. and Simon, L. 1973. Mechanism of action of 1-b-D ribofuranosyl-1,2,4-triazole-3-carboxamide (Virazole), A new broad-spectrum antiviral agent. Proc. Nat. Acad. Sci. U.S.A. 4: 1174-1178.

41. Toltzis, P. and Huang, A. 1986. Effect of ribavirin on macromolecular synthesis in vesicular stomatitis virus-infected cells Antimicrob. Agents Chemother. 29: 1010-1016.

42. Viani, R., Gutteberg, T., Lathey, J. and Spector, S. 1999. Lactoferrin inhibits HIV-1 replication in vitro and exhibits synergy when combined with zidovudine. AIDS Letter 13: 1273 1274.

43. Yamauchi, K., Tomita, M., Giehl, J. and Ellison, R. 1993. Antibacterial activity of lactoferrin and a pepsin-derived lactoferrin peptide fragment. Infect. Immun. 61: 719-728.

44. Yi, M., Kaneko, S., Yu, D.Y. and Murakami, S. 1997. Hepatitis $\mathrm{C}$ virus envelope proteins bind lactoferrin. J. Virol. 71: 5997 6002.

45. Yoshimatsu, K., Arikawa, J., Tamura, M., Yoshida, R., Lundkvist, A., Niklasson, B., Kariwa, H. and Azuma, I. 1996. Characterization of the nucleocapsid protein of hantavirus strain 76-118 using monoclonal antibodies. J. Gen. Virol. 77: 695704. 